\title{
Reconstruction Vocal and Diphthong of Ancient Sulawesi Language (BSP)
}

\section{Dr. Muhammad Nur Latif, M.Hum}

Faculty of Humanity, University of Hasanuddin, Jl. Perintis Kemerdekaan Km. 10, Makassar 90245, Indonesia

\section{Doi:10.5901/mjss.2016.v7n2s1p229}

\author{
Email: lavirgo67@yahoo.com.my
}

\section{Abstract}

This study is to reconstruct the ancient vowels and diphthongs from a language that assumed exist in South and West Sulawesi namely South Sulawesi ancient language (BSP). BSP reconstruction is executed using methodology of qualitative comparative with internal reconstruction approach. The criteria for the reconstruction approach is to determine cognate word, looking for phoneme equivalent set, determining recurrence of phonemes and determination the ancient phoneme for language of Makassar (MKS), Bugis (BGS), Massenrempulu (MSP), Toraja (TRJ), and Mandar (MDR). The results for the study shows that the reconstructed BSP has 5 vowel phonemes, ie *i, *u, ${ }^{*} 0$, ${ }^{*}$, and *a and 5 diphthong, ie *-ua, *-au, ${ }^{*}$-oe, *ai and *-uo. The presence of these ancient phonemes both of vowel phonemes or diphthongs phoneme are going regularly and predictably. The presence of several characteristics of sporadic on vowel phonemes BSP *i, *u, *0, * $\partial$, *a, and diphthong phonemes *-ua, *-au, *-oe, *ai and *-uo in specific distribution is one characteristic that describes this phenomenon occur was new and hard to explain. However, our initial assumption is this sporadic innovation occurrence is probably caused by the local migrationin the study area that appeared the characteristics of this new innovation. The BSP reconstruction study is a study on the low stage and this study has pioneered efforts to reconstruct BSP at a higher stage, by comparison the phoneme of vowel and diphthongs with the Ancient Polynesian Malay language (PMP).

Keywords: reconstruction of language; qualitative comparisons; BSP vowel; BSP diphtong

\section{Introducing}

The language found in the province of South Sulawesi is one of the Oceania languages from the Austronesian family. In the province of South Sulawesi and West have found some of the local language which are the Bugis, Makassar, Massenrengpulu, Toraja, and Mandar. These languages evolved and still actively used by its native speakers. The languages of Bugis, Makassar, and Toraja that found in South Sulawesi, while Mandar language found in West Sulawesi. Bugis tribe is belonging to the Malay Deutero tribes. It was entered the archipelago after the first phase of migration from mainland Asia, exactly Yunan. Whereas, Makassar language is referred to Basa Mangkasara $?$ is the languages spoken by the Makassar tribe. This language is inserted into a family of Makassar languages which is part of the family of South Sulawesi in the Malay-Polynesian branch from the Austronesian language.

Furthermore, language of Massenrempulu (Enrekang) is one of the languages in the Austronesian family as well and has a closeness with other languages in South and West Sulawesi. Enrekang language in a clump of Massenrempulu have closeness to the languages of Bugis, Toraja, Tae (Luwu), and Mandar, seeing the location of the speakers are located in the middle region from the speakers of the languages above. The language of Toraja-Sadan is one of the languages spoken in the region and surrounding of Tana Toraja, South Sulawesi, Indonesia. Toraja-Sa?dan has several dialects, among Makale (Tallulembangna), Rantepao (Kesu?), West Toraja (Mappa-Pana). Whereas the language of Mandar is Mandar's tribe, who live in the province of West Sulawesi, precisely in Mamuju, Polewali Mandar, Majene and North Mamuju.

Studies upon variant Makassar has actually been carried out since the beginning of the 19th century as the presence of colonial in Makassar, and in historical records found that the study of language of Makassar first performed by Matthes in 1858 were marked by his work entitled Makassarche Spraakkunst that contains the grammar stub of Makassar language. When in the colonial era, the study upon Makassar variant is just a study of collecting lexical variants and far away from the point of reviewing the linguistic variants. This variant is examined from the angle of linguistics in the 20th century and study of reconstruction in current. Considering the lack of study linked with the subject of reconstruction for this language, it is important to perform an attempt on the reconstruction to Makassar variants using comparative linguistic approach historically.

The integrity of the comparative linguistics actually leads to the attempts reconstructing the ancient form of human language. This effort is born out of spontaneous outburst pieces from the comparison linguistics experts to develop of the ancient language that ever spoken by speakers of these languages at one time ago before the language was separated into a series of varieties or variants on the moment. In order to meet the demands of their core duty for the comparative linguists, then this study will discuss all things matters relating to the reconstruction vowel phonemes and diphthongs variant of Makassar would eventually acquire the vowel phonemes and diphthongs in South Sulawesi Ancient Language (BSP). 


\section{Study Issue}

The study of ancient languages of South Sulawesi has been done by the experts, but we found that there has been no study done in order to reconstruct the BSP. The last set of research on the language has been studied to help provide an initial overview for the researchers to produce new and more in-depth description. Previous studies outlining problems in the South Sulawesi Ancient Language (BSP), which was conducted by researchers in the past usually only done by the clergy / pastor. The results of research conducted over the direction of the pattern of life of local communities. If touching aspects of language, they are only focused on collecting as many lexical item of several variants Makassar. Therefore, the main problem in this study is an attempt to reconstruct the language in order to acquire the South Sulawesi South Sulawesi language Ancient (SSP).

The problem will be answered based on a qualitative comparison of the linguistic approach through internal reconstruction. The application of qualitative methods can also be seen in the study of innovation and retention. Previous studies, mostly using approaches based on quantitative comparison lexicostatistics which of course could not generate a more complete reconstruction. The ability to reconstruct a qualitative comparison will produce a result that is more complete than the quantitative comparison based on approach lexicostatistics.

\section{Methodology}

Based on the above issues, the objectivity of this study focuses to reconstruct the vowels and diphthongs of South Sulawesi language in order to obtain the ancient form from both of these phonemes in BSP. BSP reconstruction is done based on some criteria that started by determining the kognat words that form in all languages in South Sulawesi. Secondly, after the kognat words obtained, the next step was to develop the sets of correspondent sound. Third, if the correspondence sound is obtained, the ancient phoneme of these sets can be determined. One set of the sound correspondence only generate one derivative the ancient phonemes.

Furthermore, to achieve the goals of reconstruction, BSP phonemes displayed using internal reconstruction. The method to reconstruct an ancient language has the following criteria (Crowley, T., 1992, Campbell, L., 2001 \& Ringe, D. \& Eska, JF, 2013);

i. specifying cognate words from several languages derivatives which are used as comparative language. In the event of cognate words was not obtained or has a completely different form, then that means that word may be derived from other sources ancient languages. If words has cognate, then we have to determine the degree of similarity of form and meaning. Related to this, Crowley (1992: 92) says, "If they are similar enough that it could be assumed that they are derived from a single original form with single original meaning...." It should be noted also that the determination of cognate words made after the word which shows the similarity of formmeaning caused by accidental factors, borrowing, and iconic isolated first.

ii. sorting sets of sound correspondence language compared to it. Using the data in Table 1, the set of sound correspondence can be obtained as follows:

Table 1. The cognate word of four Pacific island languages

\begin{tabular}{lllll}
\hline Tongan & $\mathrm{t}$ & $\mathrm{a}$ & $\mathrm{p}$ & $\mathrm{u}$ \\
Samoan & $\mathrm{t}$ & $\mathrm{a}$ & $\mathrm{p}$ & $\mathrm{u}$ \\
Rarotongan & $\mathrm{t}$ & $\mathrm{a}$ & $\mathrm{p}$ & $\mathrm{u}$ \\
Hawai & $\mathrm{k}$ & $\mathrm{a}$ & $\mathrm{p}$ & \\
\hline
\end{tabular}

Source: Crowley (in Rahim 2008: 28)

There are four correspondence disclosed in Table 1, the first correspondence; Tongan / $/$, Samoan / $/$, Rarotongan / $\mathrm{t} /$ and Hawaiian / $/$ /. The second, third and fourth correspondence, all language showed / a /, / p / and / $\mathrm{u} /$. The fourth sets of the correspondence can be written as shown in Table 2 below:

Table 2. The four-language correspondence Pacific islands

\begin{tabular}{cccc}
\hline Tongan & Samoan & Rarotongan & Hawai \\
t: & $\mathrm{t}:$ & $\mathrm{t}:$ & $\mathrm{k}$ \\
$\mathrm{a}:$ & $\mathrm{a}:$ & $\mathrm{a}:$ & $\mathrm{a}$ \\
$\mathrm{p}:$ & $\mathrm{p}:$ & $\mathrm{p}:$ & $\mathrm{p}$ \\
$\mathrm{u}:$ & $\mathrm{u}:$ & $\mathrm{u}:$ & $\mathrm{u}$ \\
\hline
\end{tabular}

Source: Crowley (in Rahim 2008:28) 
The set of correspondence should be done on all the words that have been listed as a cognate.

iii. Determining ancient phoneme from each sets of correspondence set or equivalence set. For each set of sound correspondence, we need to determine the ancient phonemes, ie phonemes considered derived the set of phonemic correspondence accepted in such derivatives languages. A set of phonemic correspondence only derive one ancient phoneme. Furthermore, if one set of correspondence has been determined, the next step is to ensure the set of correspondence earlier is exists in the other word pairs as well. This simply means of phonemic recurrence.

The efforts of determining an ancient phoneme is not so easy. In the reconstruction of phoneme the following principles need to be considered. According to Rahim Aman (2008: 29), some principles are:

i. The reconstruction must look at the change of the sound that is reasonable, that the sound changes generally apply to all languages in the world.

ii. A phoneme that is the most widely distribution in the derivative languages can be considered as a linear reflection of ancient phonemes.

iii. The reconstruction must fill the empty space in a phonological system of a language than created a phonological system disproportionate in that language.

iv. An ancient phonemes cannot be reconstructed until the phoneme is really exists and can be proved in derivative languages.

By then, based on reconstruction approach that has been mentioned by Crowley (1992) and Campbell (2001), reconstruction of vowel phonemes and diphthongs of Ancient Makassar language (BSP) can be done.

\section{Analysis}

Vowel phonemes and diphthongs BSP discussed in this paper is the result of the reconstruction of phonemes that have been made to the five languages found in South Sulawesi which covers different geographical locations ie languages of Makassar (MKS), Bugis (BGS), Massenrempulu (MSP ), Toraja (TRJ), and Mandar (MDR). Therefore, the result of the reconstruction that has been carried out proves that the amount of inventory and distribution of vowels phoneme and diphthongs of BSP is as shown in the following description.

The spread of BSP phoneme shows the existence of phonemes and vowel phoneme sounds and diphthongs of BSP is based on the position there are at the front, the middle / between vowels or the end of the word.

\subsection{The reconstruction of the BSP vowels}

Based on the equivalence of 200 vocabulary that has been reconstruct, it was found BSP has 5 vowel phonemes ie $/ * i$, ${ }^{*} u$, *0, ${ }^{*}$, and ${ }^{*} a, /$ which composed by a front vowel, two middle vowels, and two end vowels. The inventory of vowel phoneme BSP can be seen in Table 3.

Table 3. The inventory of BSP vowel

\begin{tabular}{|c|c|c|c|}
\hline $\begin{array}{ll}\text { Position } & \text { Presence } \\
\end{array}$ & Front & Middle & End \\
\hline $\begin{array}{l}\text { High } \\
\text { High half } \\
\text { Lower half } \\
\text { Lower }\end{array}$ & ${ }^{*} i$ & $\begin{array}{l}{ }^{*} \ominus \\
{ }^{*} a\end{array}$ & $\begin{array}{l}{ }^{*} u \\
{ }^{*} 0\end{array}$ \\
\hline
\end{tabular}

\subsection{The reconstruction of the BSP front vowel *i}

BSP has a high front vowel is *i. Vowel BSP *i is present at the starting position of word, pre-final and final syllable are closed and lowered directly in all languages in South and West Sulawesi in all of these positions. However, there is a little change has been apply and hard to explain in several languages in South and West Sulawesi against the majority of data on the position of the closed final syllable. In this position, some data shows sporadic innovations have been enacted in several of language in South and West Sulawesi when BSP * i> [iko] in, BGS, MSP, TRJ, [ikau] MKS and [i?o] (MDR) when, other data permanent /i/ in all languages in South and West Sulawesi on the position closed final syllable. Table 4 illustrates an example of a BSP reflex *i within the five BSP. 
Table 4. BSP refleks *i in 5 BSP

\begin{tabular}{|l|l|l|}
\hline BSP Vowel & Spread on position & Example of BSP refleks *i in 5 BSP \\
\hline \multirow{4}{*}{ i } & Front of the word & BSP *inai 'who'>; MKS,MSP; BGS iga; and TRJ, MDR inda? \\
\cline { 2 - 4 } & Pre-final syllable & BSP *lima 'hand'>; MKS,MSP; MDR; BGS and TRJ liman; \\
& BSP *lila 'lidah'>; MKS, BGS, and TRJ; MSP lili; MDR lela \\
\cline { 2 - 4 } & Closed final syllabe & BSP *aniso 'sucking'>; MKS,BGS maniso; MSP manisa; MDR; TRJ ma?mimmu MDR masserru \\
\hline
\end{tabular}

\subsection{The reconstruction of the BSP middle vowels * 0 and *a}

BSP has two vowel i.e. lower half middle vowels * 0 and lower middle vowel *a. Vocal BSP *o only present on the pre-final syllable and the closed final syllable. Based on a regular equivalence on both these positions in all BSP, the phoneme /a/ can be reconstructed as an ancient BSP * 0 . Therefore, it can be said the BSP vowels * ${ }^{*}$ directly derived in all BSP at prefinal syllable and the closed final syllable. Although BSP * directly derived in all BSP in the pre-final syllable position, but that was reconstructed data showed sporadic innovations have occurred when BSP * ${ }^{\circ}>$ [a] in 3 BSP i.e. BGS, MSP, and TRJ, [ə] in BSP MDR . And other data remain as [ə] in all BSP in this position. Table 5 illustrates an example of the reflex of this BSP * $\partial$ in 5 BSP.

Table 5. Refleks of BSP * $ə$ in 5 BSP

\begin{tabular}{|c|c|c|}
\hline BSP Vowel & Spread on position & Example of BSP refleks * ${ }^{*}$ in 5 BSP \\
\hline \multirow[t]{3}{*}{ *a } & Front of the word & BSP *enrə? 'go up'>;BGS enrə?;MSP and TRJende?; MDR mindai; and MKS nai? \\
\hline & Pre-final syllable & $\begin{array}{l}\text { BSP *alə? 'forest'>;BGS alə2;MSP ala?; TRJ payala?MDR payale, and MKS romay } \\
\text { BSP *mesa 'one'>; MSP, TRJ and MDR mesa; MKS se?re; BGS se?di }\end{array}$ \\
\hline & Closed final syllable & $\begin{array}{l}\text { BSP *makkeda 'say'>; BGS makkə?da;MSP mankeda?; TRJ ma?kada; MDR mappauw, and MKS } \\
\text { a?bicara }\end{array}$ \\
\hline
\end{tabular}

A further mid vowel is the lower mid vowel *a. BSP vowel*a presence in all positions of word i.e. in front, pre-final syllable, closed final syllable and the open final syllable. Base on regular equivalence on a certain position then *a phoneme can be reconstructed as the ancient phoneme BSP. Therefore, the vowel BSP *a it is directly derived in all BSP. Although BSP *a directly derived in all BSP at the front of words, but there are data showing sporadic innovations have occurred when BSP *a> [ə] in BGS and [i] in the MDR while other data remains as [a] in this position.

In addition, the data also show that the open final syllable positions also showed sporadic innovations have occurred when the vowel /a/> [an] in MSP and TRJ, while other data remains permanent as [a] in this position. Table 6 describes an example of a BSP reflex *a in five BSP.

Table 6. Refleks of BSP *a in 5 VSSP

\begin{tabular}{|l|l|l|}
\hline BSP Consonant & Spread on position & Example of BSP refleks *a in 5 BSP \\
\hline *a & Front of the Word & BSP *appa 'four'>; BGS,eppa? ; MKS, MSP and TRJ appa; and MDR appe?. \\
& $\begin{array}{l}\text { BSP *ammalli 'buy' >; MKS and MDR ammalli; BGS melli; MSP and TRJ mayyalli. } \\
\text { BSP *amma 'mother'>; BGS emma?; MSP and TRJ indo?; MDR and MKS amma? }\end{array}$ \\
\cline { 2 - 3 } & Pre-final syllable & $\begin{array}{l}\text { BSP *ula 'snake'>; BGS, MSP and TRJ ula?; MKS ulara?; and MDR ulli. } \\
\text { BSP *bale 'fish'>; BGS, MSP and TRJ bale; MDR bau; MKS juku? }\end{array}$ \\
\cline { 2 - 3 } & Closed final syllable & BSP *appa 'four'>; BGS eppa? ; MKS, MSP and TRJ appa; and MDR appe?. \\
\hline
\end{tabular}

\subsection{The reconstruction of the BSP end vowels * $u$ and *0}

BSP has two end vowel phonemes that is high end vowel * $u$ and the high half end vowel *o. The BSP high end vowel * $u$ be present in all positions of words i.e. pre-final syllable, closed final syllable and open final syllable and directly derived 
in all BSP. Based on regular equivalence in certain positions in all BSP, then the phoneme * $u$ be reconstructed as BSP ancient phoneme. Although BSP *u directly derived in all BSP at the beginning of the word, but there are data that indicate an innovation sporadically been applicable if BSP * $u>$ [ə] in MKS when, other data remain permanent as [u] in this position. Table 7 describes an example of reflex of BSP *u in five BSP.

Table 7. Refleks of BSP *u in 5 VSSP

\begin{tabular}{|l|l|l|}
\hline BSP Consonant & Spread on position & Example of BSP refleks *u in 5 BSP \\
\hline *u & Front of the word & BSP *ulu 'head'>; BGS and MDR ulu ; MKS and MSP ulu? ; TRJ uke. \\
& BSP *usus 'gut'>; MKS BGS, TRJ and MDR usus; MSP tambu? \\
\cline { 2 - 3 } & Pre-final syllable & $\begin{array}{l}\text { BSP *asu 'dog'>; BGS, MSP,TRJ, and MDR asu?; MKS konkon. } \\
\text { BSP *bale 'fish'>; BGS, MSP and TRJ bale; MDR bau; MKS juku ? }\end{array}$ \\
\cline { 2 - 4 } & Closed final syllable & BSP *mabbukka 'open'>; BGS,MSP and TRJ ma Pbukka; MDR membuai; MKS annunkei. \\
\hline & Open final syllable & $\begin{array}{l}\text { BSP *bulu 'fur'>;MKS, BGS,MSP, TRJ and MDR bulu. } \\
\text { BSP *batu 'stone' >;MKS, BGS, MSPTRJ and MDR batu. }\end{array}$ \\
\hline
\end{tabular}

Back vowel high half BSPP *o is only present on the closed final syllable position and an open final syllable. Based on regular equivalence in certain positions BSP *o directly derived in all BSP. Although it is said to be directly derived in all BSP, there are examples of data that shows the closed final word position of BSP vowel *-0- $>$ [-u-] in TRJ and MDR, [a] Accordingly, the sample data show in the open final syllable position helped reveal sporadic innovation occurs when vowel of $\mathrm{BSP}^{*}-0>[\mathrm{u}]$ in TRJ and MDR, [-a] when, other data remain permanent as [-o] in this position. Table 8 describes an example of reflex of $\mathrm{BSP}{ }^{*} \mathrm{O}$ in five BSP.

Table 8. Refleks of BSP *0 in 5 BSP

\begin{tabular}{|l|l|l|}
\hline BSP Consonant & Spread on Position & Example of BSP Refleks *u in 5 BSP \\
\hline \multirow{2}{*}{0} & Front word & -- \\
\cline { 2 - 3 } & Closed final syllable & $\begin{array}{l}\text { BSP*mantoe'hold' > ;MSPmantoe?;TRJ ma? tue;MDR matta?i; BGS ma?kateniyMKS } \\
\text { anni?gala?. }\end{array}$ \\
\hline & Open final syllable & $\begin{array}{l}\text { BSP *tallo 'egg'>;BGS tello?; MSPTRJ and MDR tallo?; MKS bayao. } \\
\text { BSP *iko 'you'>;BGS, MSP and TRJ iko ;MDR i?o; MKS ikau } \\
\text { BSP *allo 'day' >; MKS, MSP, TRJ, and MDR allo ; BGS esso }\end{array}$ \\
\hline
\end{tabular}

\subsection{The reconstruction of the BSP diphthongs}

BSP has seven diphthongs i.e. *-ua, *-au, *-oi, ${ }^{*}$ ai and *-uo, directly derived in all BSP. BSP diphthong *ua present at the middle position and end of word, and the existence of this diphthong require further validation in the field. The reviewer allege is there such a problem arises because the presence of BSP *ua is categorized as a diphthong or a sound that refers to characteristics form in BSP. However, in this study the reviewer put it first this / ua / as a diphthong phoneme perceived there is also the regularity of equivalence this diphthong in some BSP. Base on this reason the phoneme has reconstructed as an ancient phoneme BSP *ua. Table 9 below illustrates an example of a BSP reflex *-ua in all BSP.

Table 9. Refleks of BSP *ua in 5 BSP

\begin{tabular}{|l|l|l|}
\hline BSP Consonant & Spread on Position & Example of BSP Refleks *ua in 5 BSP \\
\hline *ua & Middle of the word & BSP *muane 'husband' > ;MSP, and TRJ; MDR tammuane; MKS bura?nenna; BGS lakkai \\
\hline & End of the word & BSP *tilua 'gag' > ;MSP, TRJ, and MDR tilua; BGS tallua; MKS ta?llange \\
\hline
\end{tabular}

Second diphthongs of SBSP is *-au. The BSPP -au present at the middle position and the end of the word and directly derived in all BSP. Although it is said to be derived directly in all BSP, but based on the data has showed sporadic innovation, ie BSP ${ }^{*}$-au> [-uw] in MSP and TRJ, whe, other data remain permanent as [-au] in this position. The Table 10 describes an example of reflex BSP *au in five BSP. 
Table 10. Refleks of BSP *au in 5 BSP

\begin{tabular}{|l|l|l|}
\hline BSP onsonant & Spread on Position & Example of Refleks BSP *au in 5 VSSP \\
\hline *au & Middle of the word & BSP *daun 'foliage' > ;MSP, and TRJ; MDR daun; BGS daun; MKS leko?. \\
\hline & End of the word & BSP *tau 'person'> ;MKS, BGS, and MDR tau; MSP and TRJ tauw. \\
\hline
\end{tabular}

BSP third diphthong is * ${ }^{*}$ oe. BSP -oe only present in the middle position and directly derived in all BSP. Although it is said to be directly derived in all BSP, but based on the data showed sporadic innovation, ie BSP *-oe> [-oi] in BGS when, other data remain permanent as [-oe] in this position. The Table 11 describes an example of BSP reflex *oe in five BSP.

Table 11. Refleks of BSP *oe in 5 BSP

\begin{tabular}{|l|l|l|l|}
\hline BSP Consonant & Spread on Position & Example of Refleks BSP *oe in 5 BSP \\
\hline *oe & Middle of the word & BSP *bintoen'star' > ;MKS, TRJ, MSP and MDR bintoen; BGS biccoin. \\
\hline
\end{tabular}

The fourth BSP diphthong is *-ai. BSP -ai is present at the middle position and the end of the word, and directly derived into all BSP. Although it is said to be directly derived in all BSP, but based on the data has showed sporadic innovation, ie BSP *ai> [-ae] in BGS when, other data remain permanent as [ai] in this position. The Table 12 describes an example of reflex BSP *oe in five BSP.

Table 12. Refleks of BSP *ai in 5 BSP

\begin{tabular}{|l|l|l|}
\hline BSP Consonant & Spread on Position & Example of Refleks BSP *ai in 5 BSP \\
\hline${ }^{*}$ ai & Middle of the word & $\begin{array}{l}\text { BSP *baine 'women'> ;MKS, MSP, and TRJ baine; MDR towaone ; BGS } \\
\text { ma?kunrai. }\end{array}$ \\
\hline & End of the word & BSP *wai 'water' > ;MSP, TRJ, and MDR wai; BGS wae; MKS je ?ne. \\
\hline
\end{tabular}

The fifth BSP diphthong is *-uo. BSP -uo only present at the end of a word and directly derived position in all position in BSP. When other data remain permanent as [-uo] in this position. The Table 13 describes examples of BSP reflex *uo in five BSP.

Table 13. Refleks of BSP *uo in 5 BSP

\begin{tabular}{|l|l|l|}
\hline BSP Consonant & Spread on Position & Example of Refleks BSP *uo in 5 BSP \\
\hline${ }^{*}$ uo & End of the word & BSP *tuo 'life' > ;BGS, MSP, TRJ, and MDR tuo; MKS tallasa \\
\hline
\end{tabular}

\section{Morphological Reconstruction of Ancient Sulawesi Language}

In this section the discussion focused on the matters related to the structure of word formation (morphology). Gleason (1961: 96) argues that the morphology is writing about the principle of affix merger to form a word. Meanwhile, O'Grady (1989: 89-90) explains that morphology is a discipline of linguistics that aims to establish a set of rules of word formation. Based on the some of the reasons can be suggested that the morphology is a branch of linguistics that studies affix and how it is structured to form a word.

Morphological aspects in Ancient Sulawesi language (BSP), which will be discussed in this section are related to the affix. Affix BSP consists of sixteen affixes, i.e. nine prefix, two infix, three suffix and two confix. The nine prefix namely: $\{a ?\},\{$ ni- $\},\{$ ta $2-\},\{m a-\},\{s i-\},\{$ pa- $\}\{$ di- $\},\{$ ri- $\}$ and $\{$ pi- $\}$. While the infix namely $\{-\operatorname{im}-\}$, and $\{$-ar- $\}$. Further, the BSP sufix base on the data have three sufix namely $\{-a y\},\{-i\}$ and $\{-n a\}$. And the last, there is two confix namely $\{k a-a y\}$ and $\{$ pa-an\}. To limit this article, only the affix that exists in South and West Sulawesi will be discussed.

\section{Ancient Sulawesi Language Affixation System}

The affix system in the Ancient Sulawesi language (BSP) has 16 type of Affix base on the data in this study. The affix types such as mentioned above is composed of nine prefix, two infix, three suffixes, and two confix. the existence of these affix will be explained using the lexical phonology theory as follows: 


\subsection{Prefix in BSP}

The prefix verb that form in the BSP has nine prefix i.e. $\{a ?\},\{$ ni- $\},\{$ ta?- $\},\{$ ma- $\},\{\mathrm{si}-\},\{\mathrm{pa}-\}\{\mathrm{di}-\},\{\mathrm{ri}-\}$ and $\{\mathrm{pi}-\}$. They are the most dominant prefix found. Base on the data, prefix \{a?\}means active verbs. Example:

[a?-] + [baju] $\rightarrow$ [a?baju] 'memakai baju' (wearing clothes)

[a?-] $+[$ sikko] $\rightarrow$ [a?sikko] 'mengikat' (binding)

[a?-] + [jaiy] $\rightarrow$ [a? jaiy] 'menjahit' (sewing)

In Bugis, Mandar, Massenrempulu and Toraja, the prefix \{ma-\} $\rightarrow$ [ma?-] + [baju] $\rightarrow$ [ma?baju] 'memakai baju' (wearing clothes), [ma?ssio] 'mengikat' (binding), [ma?jaiy] 'menjahit' (sewing). Further, the prefiks \{ni-\} have means as pasive verbs. Example: [ni-] + [tobo?] $\rightarrow$ [nitobo?] 'ditikam' (stabbed), while in Toraja, Mandar, Massenrmpulu using the prefix \{di-\} and in Bugis using the prefix \{ri-\}. As for the prefiks \{ta?-\} found in Bugis, Makassar, Massenrempulu, Mandar and Toraja. Example: [ta?] + [tuwnu?] $\rightarrow$ [ta?tuwnu] 'terbakar' (burnt).

The prefix \{si-\} in Makassar, Bugis, Massenrempulu, Mandar and Toraja have means 'reciprocal, mutually'. Example: [si-] + [bombe] $\rightarrow$ [sibombe] 'saling bermusuhan' (mutually hostile). Further, the prefiks $\{$ pa- $\}$ in Makassar, Bugis, Massenrempulu, Mandar and Toraja means 'tukang/profesi' (handyman). Example: [pa-] + [sassa?/sessa] $\rightarrow$ [passassa?/sessa] 'tukang cuci' (laundress). While the perfiks \{pi-\} in Makassar, Bugis, Massenrempulu, Mandar and Toraja means 'bilangan/kali' (number of times). Example: [pi-] + [telluw] $\rightarrow$ [pitelluw/pintallu] 'tiga kali' (three times).

\subsection{Infix in BSP}

Base on the data, the affix system in BSP have two infix i.e. $\{$-im- $\},\{$-ar- $\}$. The infiks [-im-] in basic word has no change in the BSSBP. Example; [sombala?] + [-im-] $\rightarrow$ [simombala?] 'layar' (screen) and in word [turuy] + [-im-] $\rightarrow$ [timurun 'berkelanjutan' (sustainable). Furthermore, the word formation that formed from the affixation (infix) [-ar-] it is has different rule with [-im-] in BSSBP. The affixation (infix) [-ar-] leads to changes in the basic form that followed. Example: [gigi] + [-ar]- $\rightarrow$ [gari?gi?] 'gerigi'.

\subsection{Suffix in BSP}

Base on the data, there are three suffix in BSP i.e. $\{$-ap\}, $\{-i\}$ and $\{$ na- $\}$. The suffix $\{$-ạ $\}$ have function to form a noun. The [-an] suffix have no change if it is connected with a basic word.

\section{Example:}

[atoro?] + [-ay] $\rightarrow$ [ato:ray] 'undang-undang' (regulation)

[urusu?] + [-ay] $\rightarrow$ [urusan] 'beringus' (runny nose)

Furthermore, the suffix [-i] in BSP have function to forming a verb which states a command if it is followed by a verb or a noun. However, when followed by the adjective the functions are changed to declare a state as the basic word form.

\section{Example:}

[mattunu] $+[-i] \rightarrow$ [mattunui] 'membakar' (burning)

[pikkiri?] $+[-i] \rightarrow$ [pikkiri?i] 'pikirkan' (thinking)

[masiri?] + [-i] $\rightarrow$ [masiri?i] 'malu' (embarrassed)

And the suffix \{na-\} in BSP contains two meanings, namely that the meaning of 'belonging' and meaning 'superlative'.

Example:

[liman] + [-na] $\rightarrow$ [limanna] 'tangannya' (his/her hands)

[lila] + [-na] $\rightarrow$ [lilana] 'lidahnya' (his/her tongue)

[kuttu] + [kuttu:na] $\rightarrow$ 'sangat malas' (very lazy) 


\subsection{Confix in BSP}

Base on the data, there are two confix in BSP i.e. $\{k a-a \eta\}$ and $\{p a-a \eta\}$. The confix [ka-ay] very productive so that the derivative words has generated quite a lot in BSP. The confix is aimed to form the verb, whereas the meaning is appropriate with its basic word form. The confix [ka-an] when it ends with a vowel / o /, / e /, / i / and / u /, it followed by allophones without causing modification on the derivatives and the basic word.

\section{Example:}

$$
\begin{aligned}
& \text { [ka-ap] }+ \text { [ta:wu] } \rightarrow \text { [kata:wuwan] } \rightarrow \text { 'kemaluan' (genitals) } \\
& \text { [ka-an] + [pore:] } \rightarrow \text { [kaporeyan] } \rightarrow \text { 'kehebatan' (grandeur) } \\
& \text { [ka-ay] + [tindo:] } \rightarrow \text { [katindowan] } \rightarrow \text { 'ketiduran' (oversleep) } \\
& \text { [ka-ay] + [susu] } \rightarrow \text { [kasusuway] } \rightarrow \text { 'susuan' (milk) }
\end{aligned}
$$

Furthermore, the confix [pa-an] in BSP is different with the confix [ka-ay] because the [ka-] element does not change to forming a words, the change is only in the suffix [-an]. Whereas for the confix [pa-an] both change.

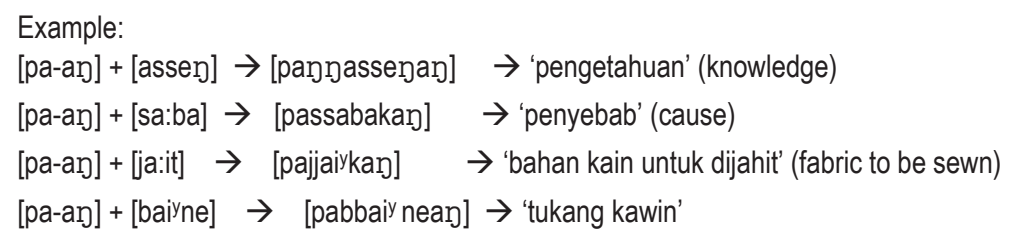

\section{Conclusion}

Actually, the history of the development of the study of South and West Sulawesi variants take a long period, over 150 years. During the colonial era in the province of South Sulawesi (the 18th century) the colonial administrators reviewing South Sulawesi variants on the basic needs in order to know the social system so that a continual colonial can be carried out on them. Various lexical variants studied and analyzed although in a more accurate assessment, namely in terms of linguistics has not been done. Linguist formal involvement and focus in reviewing South Sulawesi variant is just a new force in the mid and late 20th century. The beginning of the 21st century, studies on this variant continues to be done by linguists until the study in reconstruction aspects was begun. However, the study of the reconstruction is still using the old method, ie lexicostatistics.

Therefore, the studies presented in this report is the latest one, using a more comprehensive qualitative comparison according to the nature of change in a natural language. Five BSP were studied, i.e. Makassar (MKS), Bugis (BGS), Massenrempulu (MSP), Toraja (TRJ), and Mandar (MDR). The results show that the reconstructed BSP produces 5 vowel phonemes, ie ${ }^{*}$, " ${ }^{*} u,{ }^{*} 0$, ${ }^{*}$, and ${ }^{*} a$, and five diphthong, ie ${ }^{*}$-ua, ${ }^{*}$-au, ${ }^{*}-0 e,{ }^{*}$ ai and ${ }^{*}$-uo. Sporadic innovations that occur either on vowel phonemes or diphthong phonemes, as expressed in previous discussions show that this form of innovation is still new. The possibility of the innovation is due to internal migration that was spreading the characteristic in the region that has been used as the study location. The result of this study of the reconstruction ancient phonemes BSP are some of form of ancient word BSP is obtained and allow the next reconstruction ie lexical reconstruction BSP.

Morphological aspects in Ancient Sulawesi language (BSP) are related to the affixation system. There are sixteen affix in BSP i.e. nine prefix: $\{$ a? $\},\{$ ni-\}, \{ta?-\}, \{ma-\}, \{si-\}, \{pa- $\}\{$ di- $\},\{$ ri- $\}$ and $\{$ pi- $\}$; two infix $\{$-im- $\}$ and $\{$-ar- $\}$; three suffix: $\{-\mathrm{an}\},\{-\mathrm{i}\}$ and $\{-\mathrm{na}\}$; and two confix $\{k a-a \eta\}$ and $\{$ pa-an\}.

\section{References}

Basang, J. and Aburaerah Arief. 1981. Structure of Language Makassar. Jakarta; Guidance and Development Center to Discuss the Ministry of Education and Culture. (Basang, J. dan Aburaerah Arief. 1981. Struktur Bahasa Makassar. Jakarta; Pusat Pembinaan dan Pengembangan Bahas Departemen Pendidikan dan Kebudayaan).

Bellwood.P. 2000. Prasejarah kepulauan Indo-Malaysia. Edisi Revisi. Jakarta: Gramedia Pustaka.

Blust, Robert A. (1974). Proto-North Sarawak vowel deletion hypothesis. Ph.D. Dissertation: Universiti of Hawaii.

Campbell, L. (2001). Historical Linguistics: An introduction. Cambridge: The MIT Press.

Crowley, T. (1992). An introduction to Historical Linguistics. Auckland: Oxford University Press. 
Friberg, B. (ed). 1990. Sulawesi Language Texts. Dallas, the Summer Institute of Linguistics. 115 pp. (language Data AsiaFacific series 15.

Dola, Abdullah. 2005. Generative Phonology Language Makassar. Makassar: State University of Makassar Press. (Dola, Abdullah. 2005. Fonologi Generatif Bahasa Makassar. Makassar: State University of Makassar Press).

Fox, 2010. The significance of the comparative methods. Diakses, 23 Pebruari. Halfian, http: /halfian.multiply.com/journal/item/104. Diakses 13 November 2009.

Gleason, H.A. 1961. An introduction to descriptive linguistics. New York: Holt, Renehart.

Keraf, G. 1991. Comparative Historical Linguistics. Jakarta: Gramedia Pustaka (Keraf, G. 1991. Linguistik Bandingan Historis. Jakarta: Gramedia Pustaka)

Kridalaksana. 2009. Dictionary of Linguistics. Jakarta: PT Gramedia. (Kridalaksana. 2009. Kamus Lingusitik. Jakarta : PT Gramedia).

Latif, Muhammad Nur. 2014. The History of Malays in Borneo Island Based On Linguistic Facts. Journals Advances in Natural and Applied Sciences, 8(3) March 2014, Pages: 114-126.

Latif, Muhammad Nur. 201. Austronesian Languages in South Sulawesi: A Potrait of Proto Makassar Language Journals Advances in Natural and Applied Sciences, 9(1) January 2015, Pages: 1-5

Noorduyn, J. 2011. A Critical Survey of Studies on the Language of Sulawesi. Leiden: KITLV Press.

Nur Kartini. 2007. Genetic relationship Makassar languages and dialects Selayar Lakiung dialect. Thesis S2 Graduate Program, State University of Makassar. (Nur Kartini. 2007. Kekerabatan bahasa Makassar dialek Lakiung dengan dialek Selayar. Tesis S2 Program Pascasarjana Universitas Negeri Makassar).

Mahsun. 1995. Diachronic dialectology, an Introduction.Yogyakarta: Gadjah Mada University Press. (Mahsun. 1995. Dialektologi Diakronis, Sebuah Pengantar.Yogyakarta: Gadjah Mada University Press).

Mahsun. 2012. Research Methods Language (Stages Strategies, Methods and Technique) Revised Edition. Jakarta: PT. King Grafindo Persada.(Mahsun. 2012. Metode Penelitian Bahasa (Tahapan Strategi, Metode danTekniknya) Edisi Revisi. Jakarta: PT. Raja Grafindo Persada).

Matthes B.F. 1958. Makassararche Spraakkunst. Amsterdam: Het Nederlandsch Bijbelgenootschap.

Mulya, Abdul Kadir. 1997. Structure of English phonemes Makassar. Ujung Pandang: Language Research Institute of the Ministry of Education and Culture. (Mulya, Abdul Kadir. 1997. Struktur Fonem Bahasa Makassar. Ujung Pandang: Balai Penelitian Bahasa Departemen Pendidikan dan Kebudayaan).

Miss, CA 1967. Comparative Studies 2 Austronesian language. Kuala Lumpur: Oxford University Press. (Mees, C. A. 1967. IImu Perbandingan Bahasa 2 Aunstronesia. Kuala Lumpur: Oxford University Press).

Murmahyati. 2007. Reconstruction of languages Makassar, Bugis, Toraja, and Massenrempulu. Journal of Language Centres Makassar, ISSN: 0854- 4220. (Murmahyati. 2007. Rekonstruksi bahada Makassar, Bugis, Toraja, dan Massengrempulu. Jurnal Balai Bahasa Makassar, ISSN: 0854-4220).

Noorduyn, J. 2011. A Critical Survey of Studies on the Language of Sulawesi. Leiden: KITLV Press.

Nur Kartini. 2007. Kinship Makassar languages and dialects Selayar Lakiung dialect. Thesis S2 Graduate Program, State University of Makassar.Nur Kartini. 2007. (Kekerabatan bahasa Makassar dialek Lakiung dengan dialek Selayar. Tesis S2 Program Pascasarjana Universitas Negeri Makassar).

O' Grady, W. \& Aronoff, M. 1989. Contemporary linguistics : an introduction. New York : St. Martin's.

Pelengkahu, R. A., et al. 1971. Dialect Konjo in South Sulawesi, a report of the National Language Research Institute branches III. Ujung Pandang.(Palengkahu, R. A., dkk. 1971. Dialek Konjo di Sulawesi Selatan suatu laporan Penelitian Lembaga Bahasa Nasional Tjabang III. Ujung Pandang).

Pelengkahu, RA 1974. Map Language South Sulawesi. Ujung Pandang: National Language Institute Branch III. (Palengkahu, R. A. 1974. Peta Bahasa Sulawesi Selatan. Ujung Pandang: Lembaga Bahasa Nasional Cabang III).

Pattiasina, J.F., et al. 1976/1977. Structure Malay Makassar Language. Ministry of Education and Culture of Ujung Pandang. (Pattiasina, J.F., dkk. 1976/1977. Sturktur Bahasa Melayu Makassar. Departemen Pendidikan dan Kebudayaan Ujung Pandang).

Peter, Roach. 1998. English Fhonetics and Fonology a Practical Cours. New York: Pearson.

Rahim Aman. 1997. Why confuse the quantitative approach. Light language. 10 (7): 26-27. (Rahim Aman. (1997). Mengapakah pendekatan kuantitatif mengelirukan. Pelita Bahasa 10 (7): 26-27).

Ringe, D. \& Eska, J. F. (2013). Historical linguistics: Toward a twenty-first century reintegration. New York: Cambridge University Press.

Ray, S. H. 1926. Comparative Studi of The Melanesian Island Languages. Cambridge: Cambridge University Press.

Revand, T. com / 2011 / Territory-state-unity-republic-Indonesia-nkri.html. accessed on 18 April 2011.(Revans, R. com/2011/wilayahnegara-kesatuan-republik-indonesia-nkri.html. diakses 18 April 2011).

Tambunan. 2006. Reconstruction protobahasa Kulisusu, Wawonii, and Moronene In Southeast Sulawesi. Dissertation, University of Hasanuddin, Makassar.(Tambunan. 2006. Rekonstreuksi proto bahasa Kalisusu, Wawonii, dan Moronenedi Sulawesi Tenggara. Disertasi, Universitas Hasanuddin, Makassar).

Tryon, D. 1995. The Austronesians: Historical and Comparative Perspective. Camberra.: Departement of Antropology. 